\section{$\frac{110}{10-6.77}$}

\section{FNERGY}

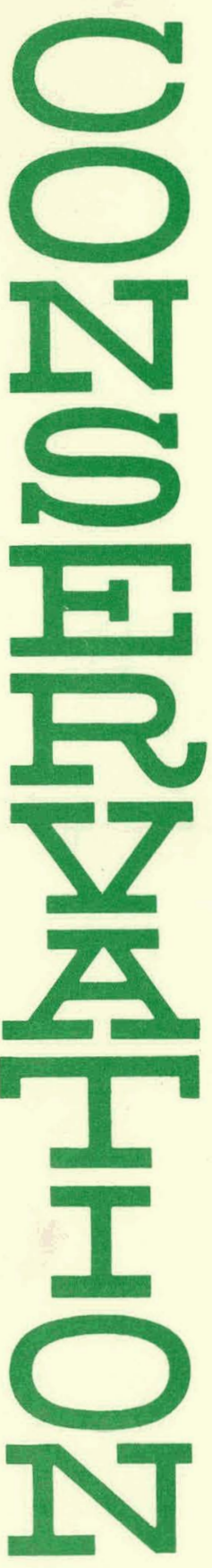

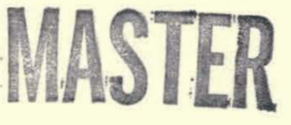

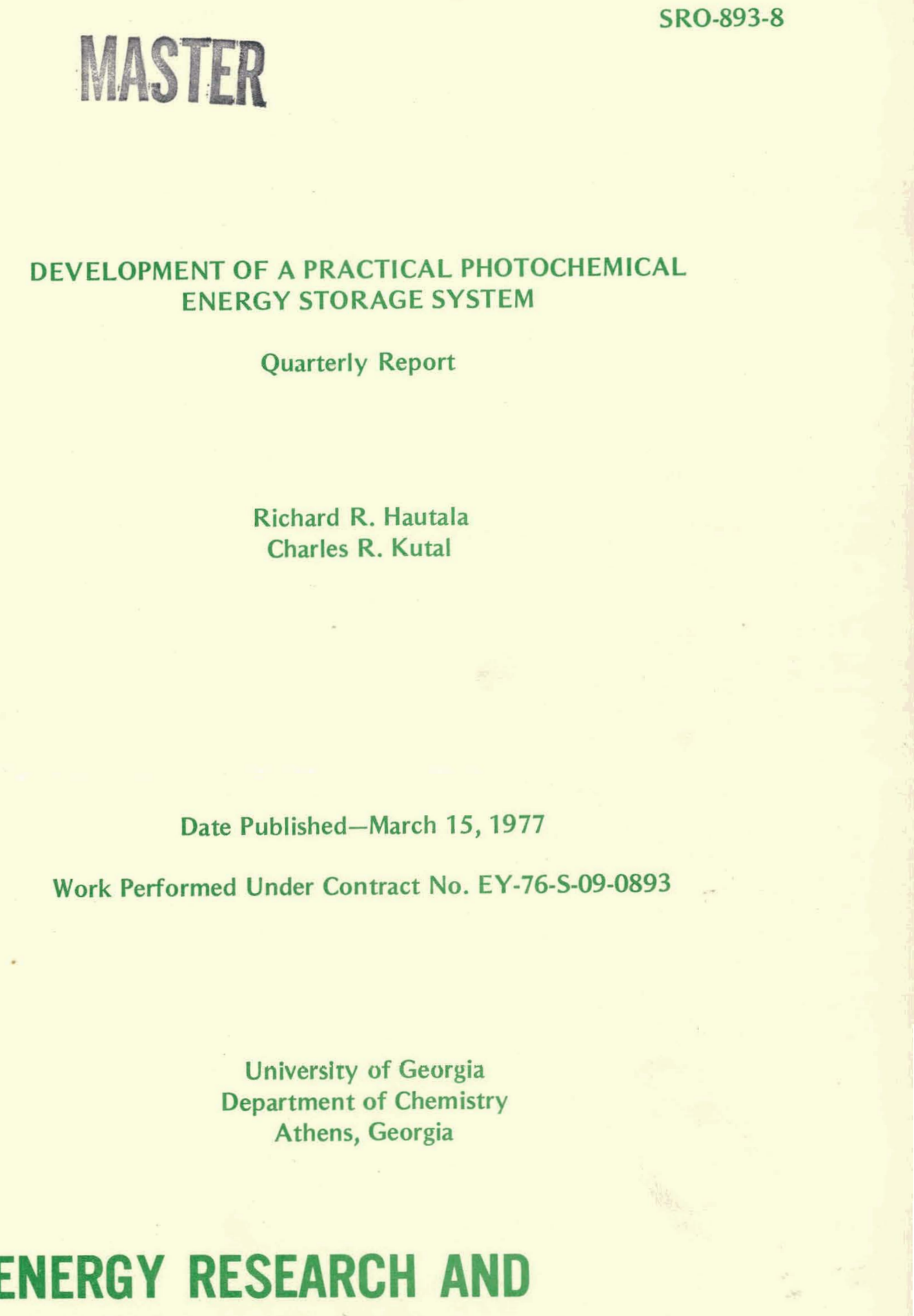

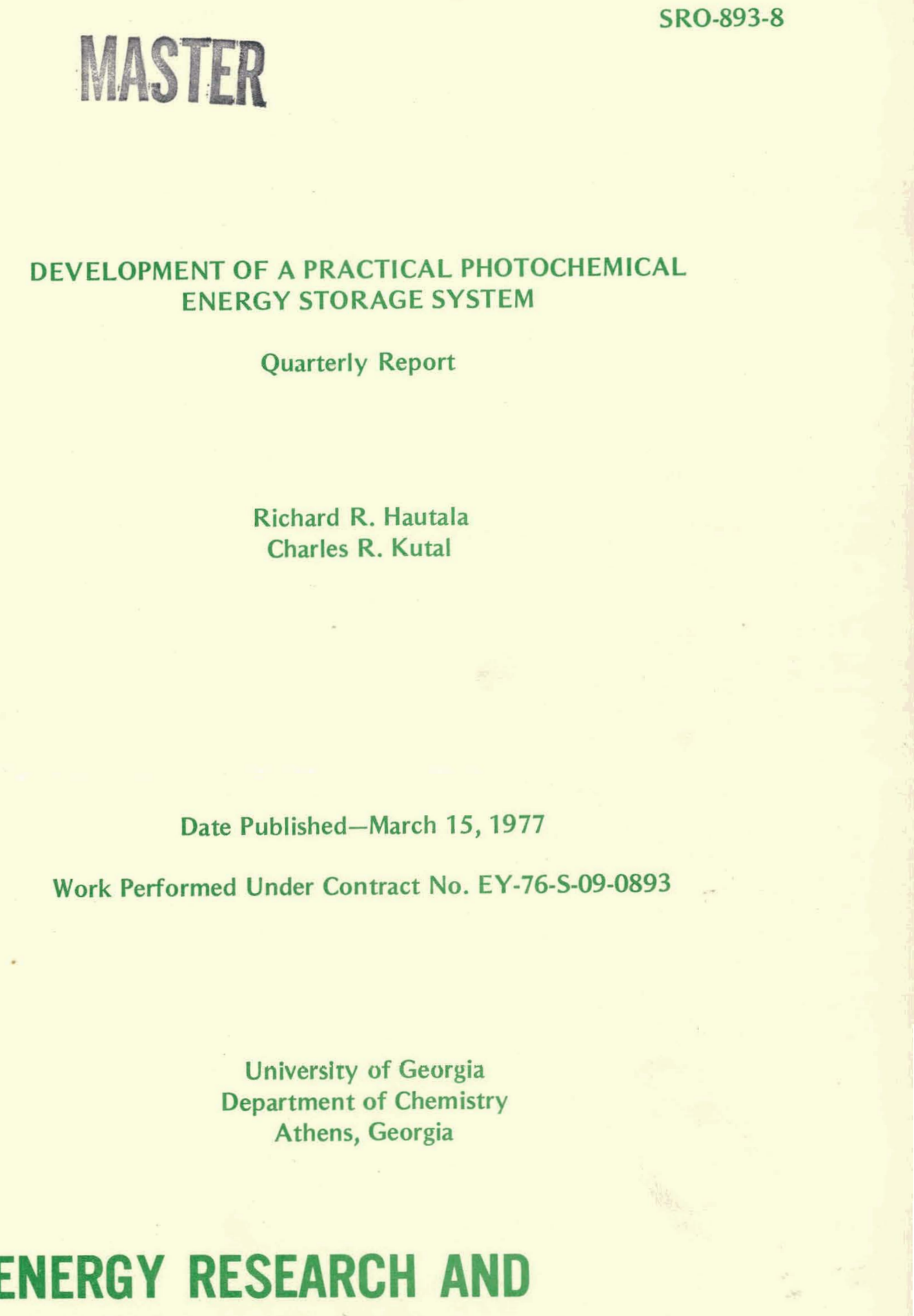

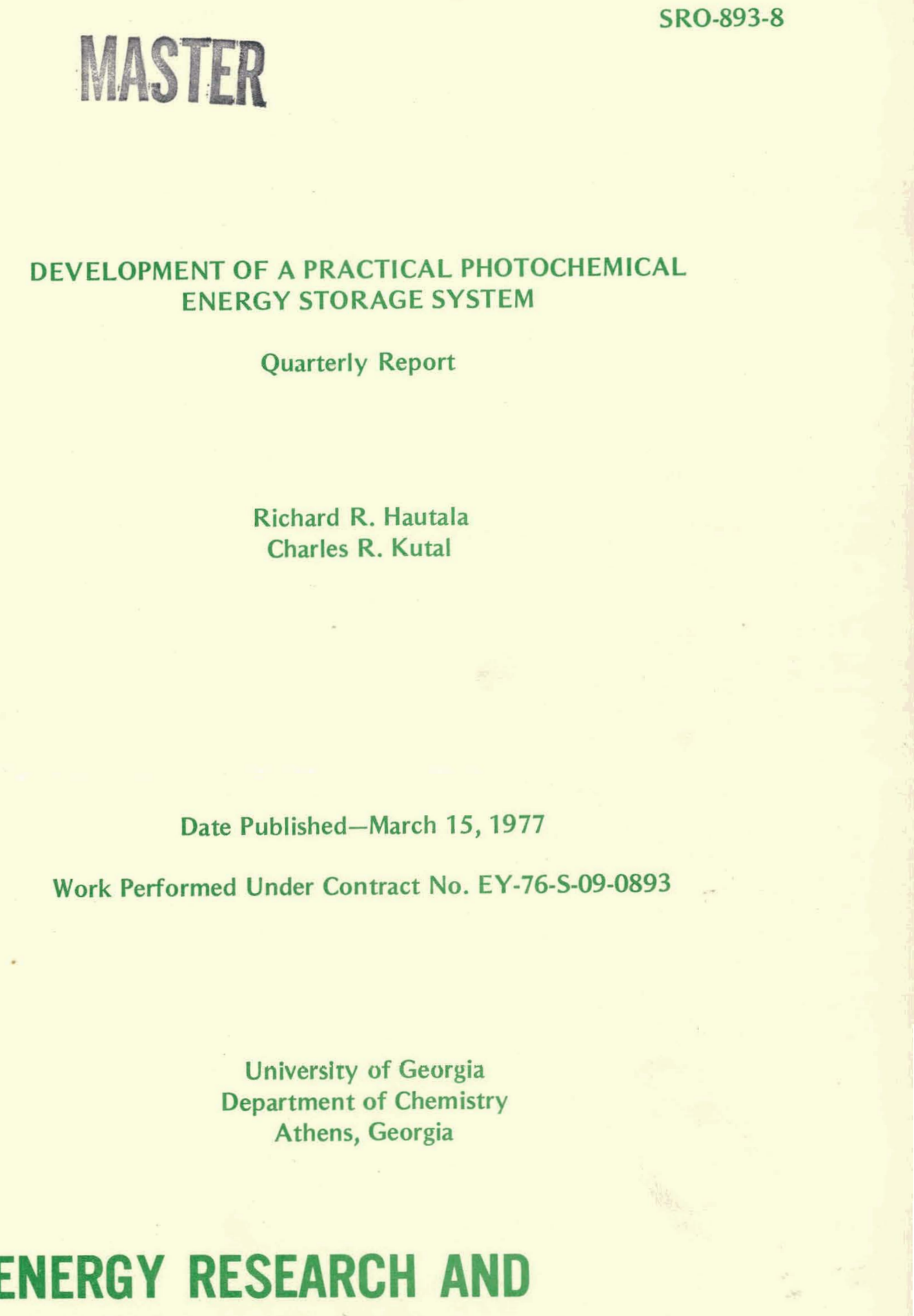

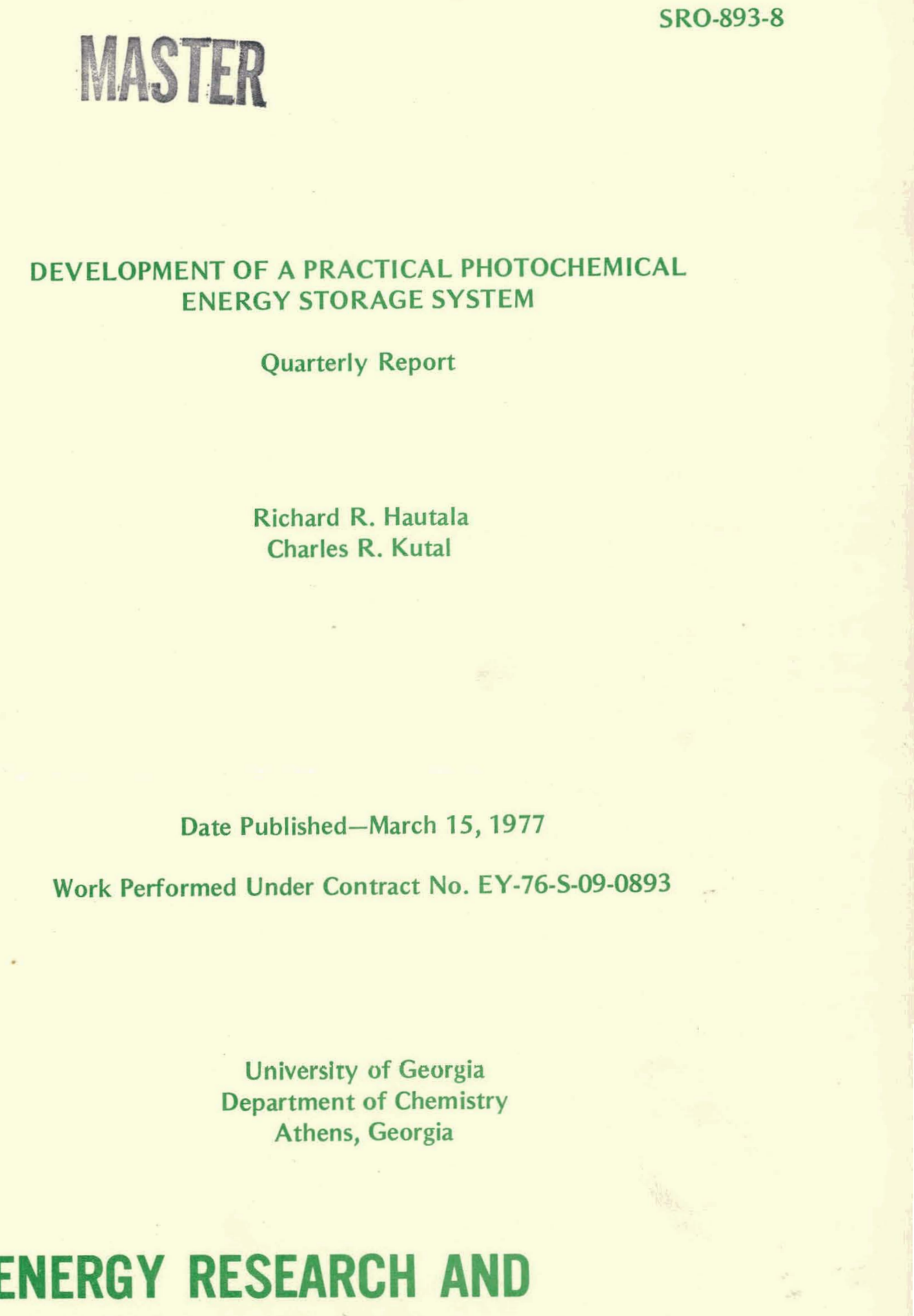

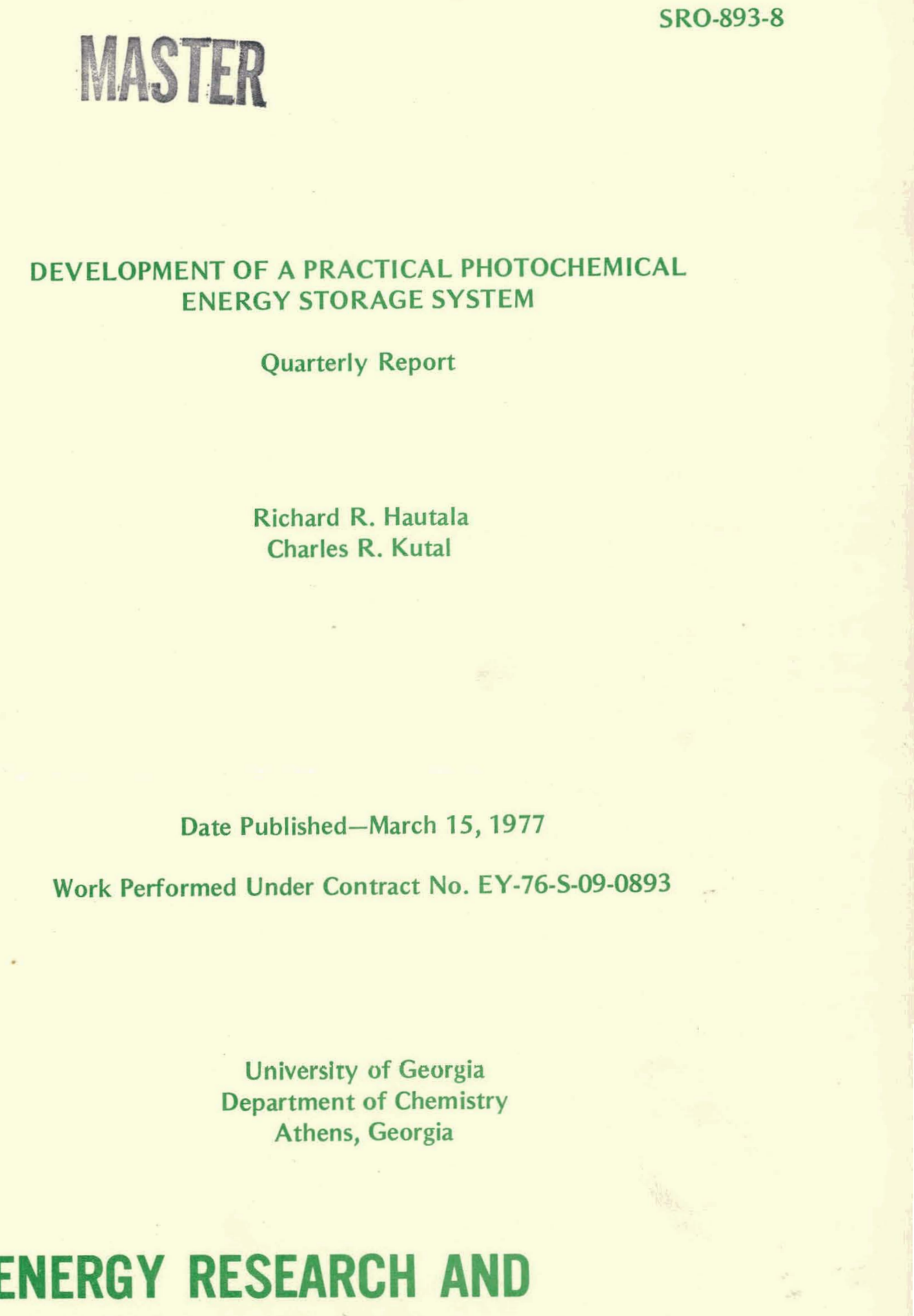

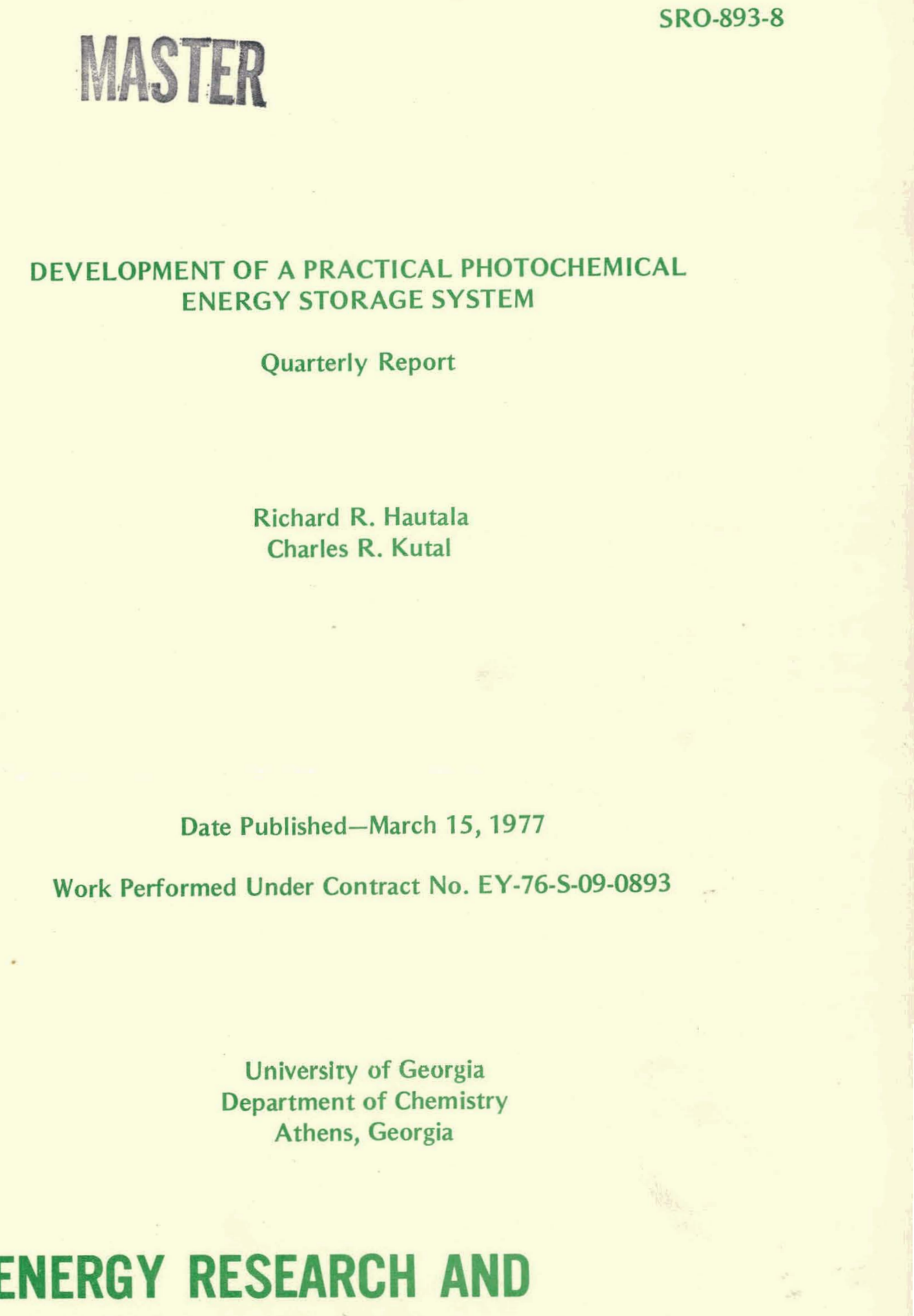

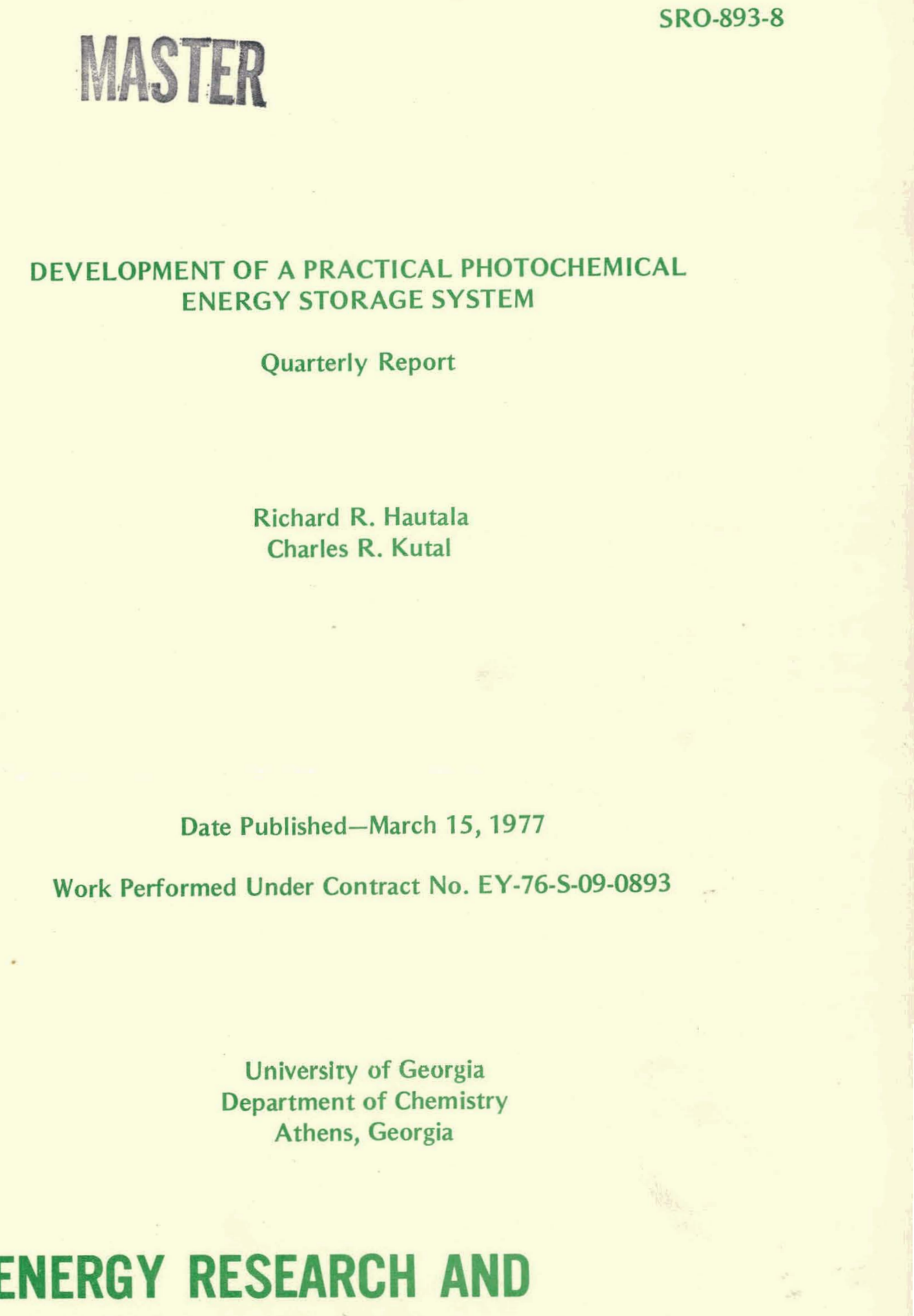

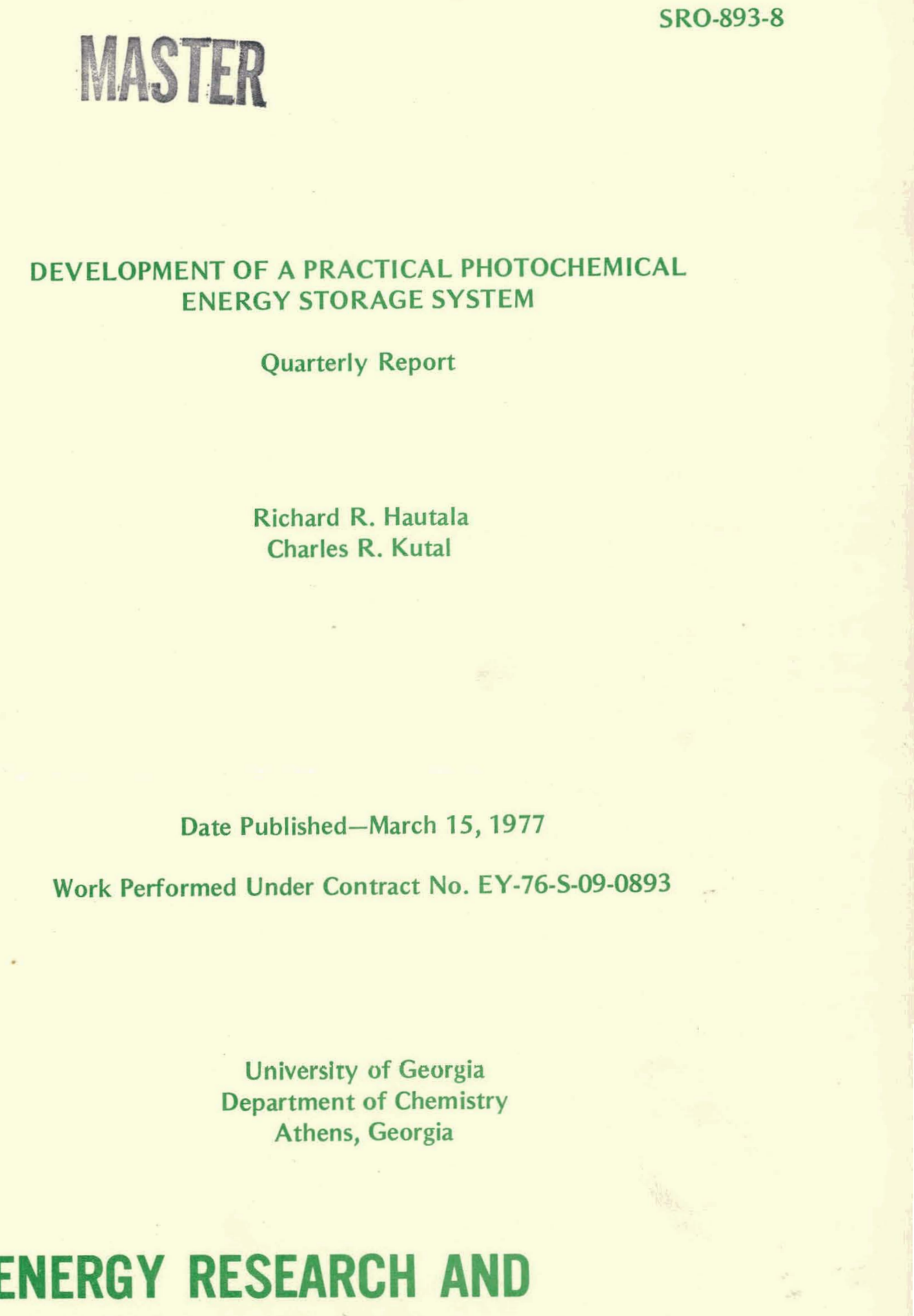

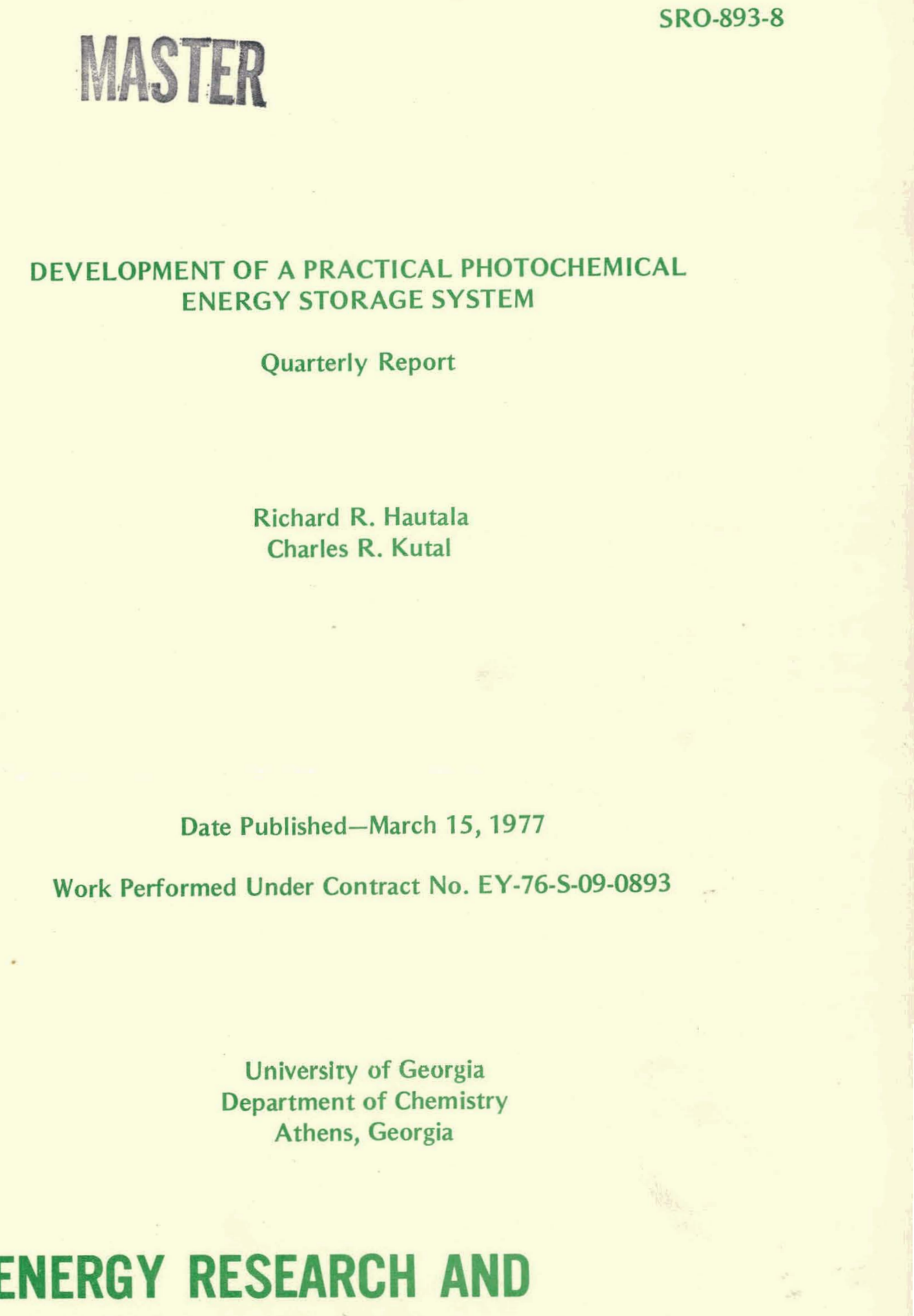

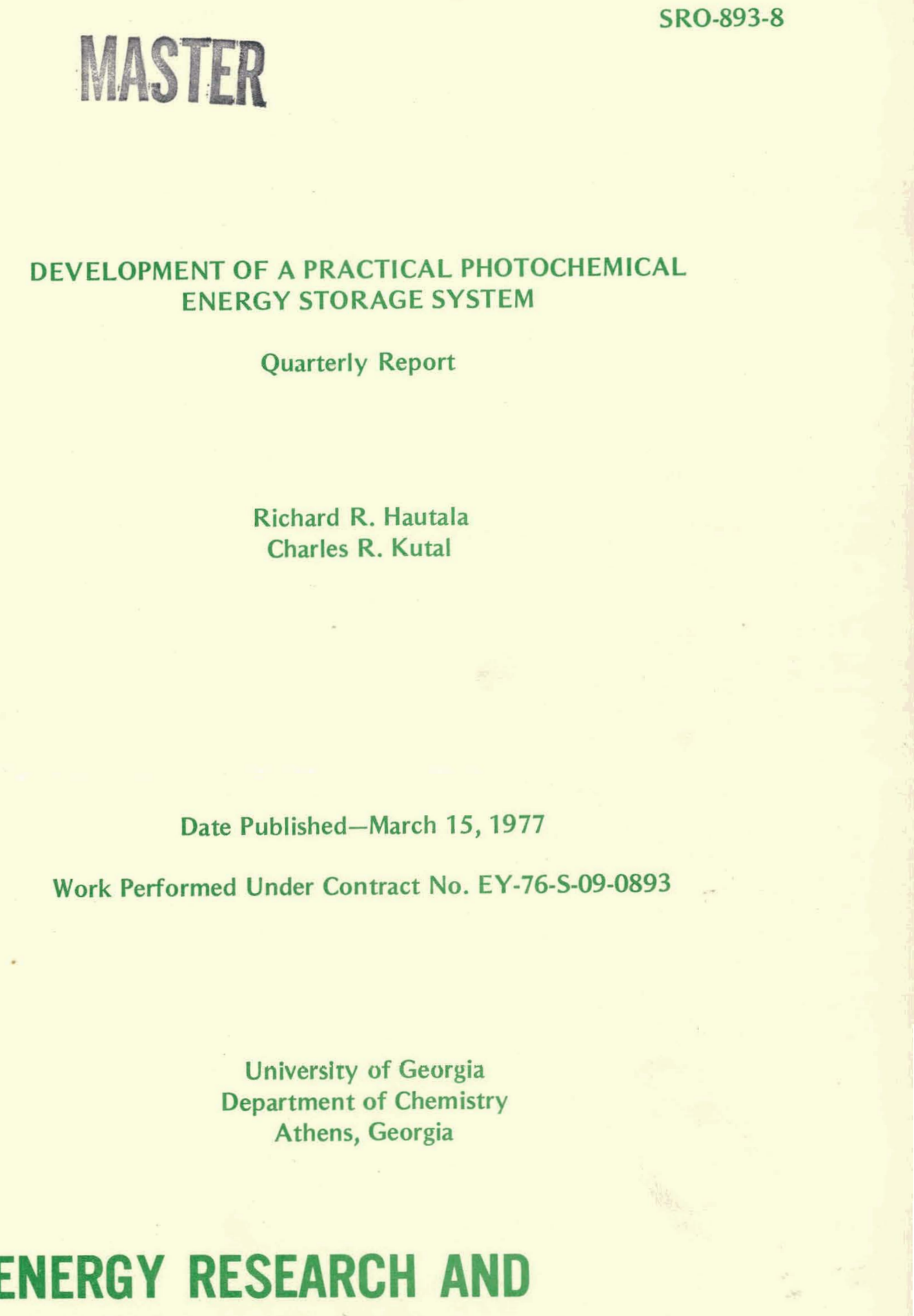

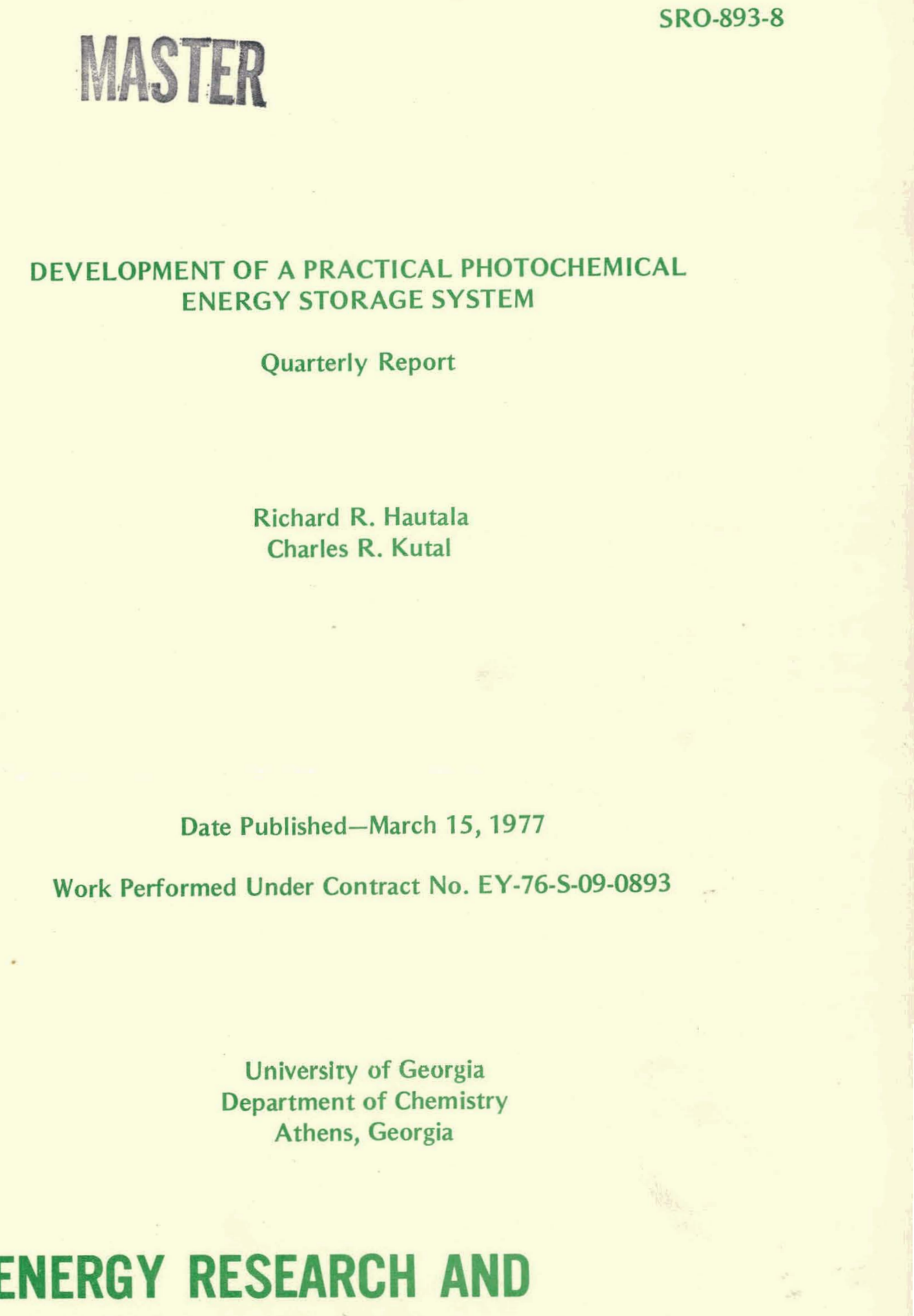
\title{
DEVELOPMENT ADMINISTRATION
}

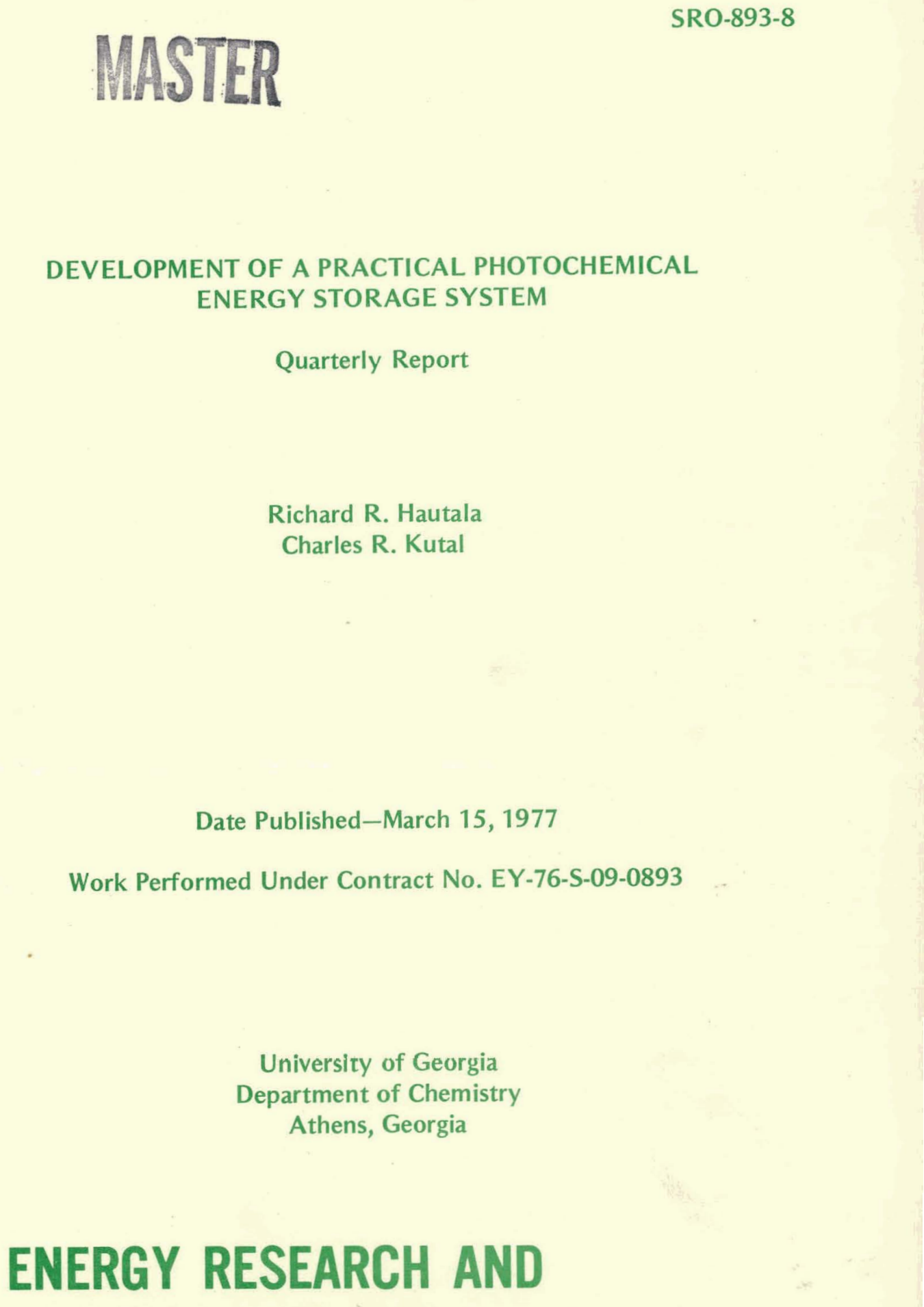

\author{
Division of Energy Storage Systems
}




\section{DISCLAIMER}

This report was prepared as an account of work sponsored by an agency of the United States Government. Neither the United States Government nor any agency Thereof, nor any of their employees, makes any warranty, express or implied, or assumes any legal liability or responsibility for the accuracy, completeness, or usefulness of any information, apparatus, product, or process disclosed, or represents that its use would not infringe privately owned rights. Reference herein to any specific commercial product, process, or service by trade name, trademark, manufacturer, or otherwise does not necessarily constitute or imply its endorsement, recommendation, or favoring by the United States Government or any agency thereof. The views and opinions of authors expressed herein do not necessarily state or reflect those of the United States Government or any agency thereof. 


\section{DISCLAIMER}

Portions of this document may be illegible in electronic image products. Images are produced from the best available original document. 


\section{NOTICE}

This report was prepared as an account of work sponsored by the United States Government. Neither the United States nor the United States Energy Research and Development Administration, nor any of their employees, nor any of their contractors, subcontractors, or their employees, makes any warranty, express or implied, or assumes any legal iiability or responsibility for the accuracy, completeness or usefulness of any information, apparatus, product or process disclosed, or represents that its use would not infringe privately owned rights.

This report has been reproduced directly from the best available copy.

Available from the National Technical Information Service, U. S. Department of Commerce, Springficld, Virginia 22161

$$
\text { Price: Paper Copy } \$ \frac{1}{\$ .50} \text { (domestic) }
$$

Microfiche $\$ 3.00$ (domestic)

$\$ 4.50$ (foreign) 


\title{
DEVELOPMENT OF A PRACTICAL PHOTOCHEMICAL ENERGY STORAGE SYSTEM \\ Quarterly Report
}

\author{
Richard R. Hautala and Charles R. Kutal
}

March 15, 1977

UNDER CONTRACT E(38-1)-893

PREPARED FOR

ENERGY RESEARCH AND DEVELOPMENT ADMINISTRATION

Deportment of Chemistry

University of Georgia

Athens, Georgia 30602

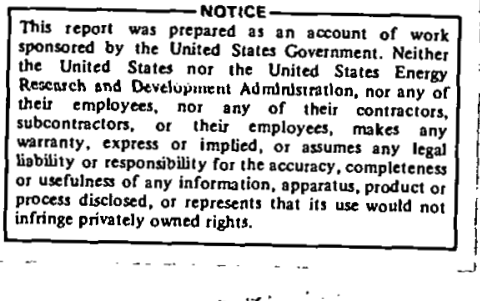

Une United States Sor any of

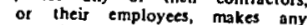
impied, or assumes any legal process disclosed, or represents that its use would not infringe privately ouned rights. 


\section{POLYMERIC ORGANIC SENSITIZERS}

Several organic sensitizer chromophores have been incorporated into insoluble polymeric matrices. Each of these has been compared to the corresponding soluble monomer with respect to sensitization efficiency. We have previously reported some of these comparisons.' Our previous studies, however, were done with solvents that minimize polymer swelling (e.g. cyclohexane). Under such conditions, light reflection from the polymer beads probably contributes to reduced observed quantum efficiencies. Thus, we studied the sensitization efficiency of three polymer (structures below) using benzene as a solvent. Under these condirions, the polymer swells and light reflectance losses are minimized. The results of this study are presented in Table 1.<smiles>CCCC(C)c1ccc(C(C)=O)cc1</smiles>

$\underline{A}$<smiles>CCC(CC)c1ccc(C(=O)c2ccccc2)cc1</smiles>

B<smiles>CCC(CC)c1ccc(C(=O)c2ccccc2)cc1</smiles><smiles>CC(C)(C)C</smiles>

$\mathrm{N}$

Table 1. The effect of solvent on the sensitization efficiencies using a variety of functionalized polymeric sensitizers. (a)

Polymer (b)

$\mathrm{N}-20$

$\mathrm{N}=20$

$\mathrm{N}-2$

$A-2$

$A-2$

$B-20$

$B-20$
Solvent

cyclohexane

benzene

benzene

cyclohexane

benzene

cyclohexane

benzene

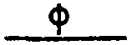

0.55

0.72

0.75

0.25

0.14

0.046

0.12

(a) carried out at $313 \mathrm{~nm}$ with solutions containing $0.5 \mathrm{M}$ Norbornadiene

(b) the number refers to the $\%$ crosslinking of the polymer 
For a number of reasons, Polymer $\mathrm{N}$ is clearly the best available polymeric sensitizer for the conversion of norbornadiene to quadricyclene and the bulk of our studies have been focused on this system. We have examined the influence of the type of polystyrene used to prepare this polymer and the synthetic sequence employed. In Table 2 are data which further indicate that only a small difference exists between using $2 \%$ or $20 \%$ crosslinked polystyrene.

Table 2. Comparison of the $2 \%$ and $20 \%$ crosslinked Polymer $N$ in benzene using $0.5 \mathrm{M}$ nurbornudiene sulutions.

\begin{tabular}{clc} 
\%o crosslinking & $\frac{\lambda^{\text {excit }}}{\Phi}$ \\
\hline 2 & 313 & 0.75 \\
2 & 366 & 0.71 \\
20 & 313 & 0.72 \\
20 & 366 & 0.92
\end{tabular}

The extinction coefficient for the dimethylamino benzophenone chromophore (used in Polymer N) falls off sharply beyond $400 \mathrm{~nm}$ and approaches a value of 1 at $435 \mathrm{~nm} .^{2}$ Consequently, we expected that with only low to moderate functionalization, the apparent quantum efficiencies would fall markedly at longer wavelengths using these polymers. In Table 3, the ratio of quantum yields at $406 \mathrm{~nm}$ compared to that at $366 \mathrm{~nm}$ is presented for two varieties of the $20 \%$-crosslinked Polymer $N$. Each was prepared in an identical fashion according to Scheme I but the condensing ester varied from ethyl to methyl. The latter was expected to functionalize more efficiencly, and the ratios support

Scheme I. Preparative scheme for Polymer $\mathrm{N}$
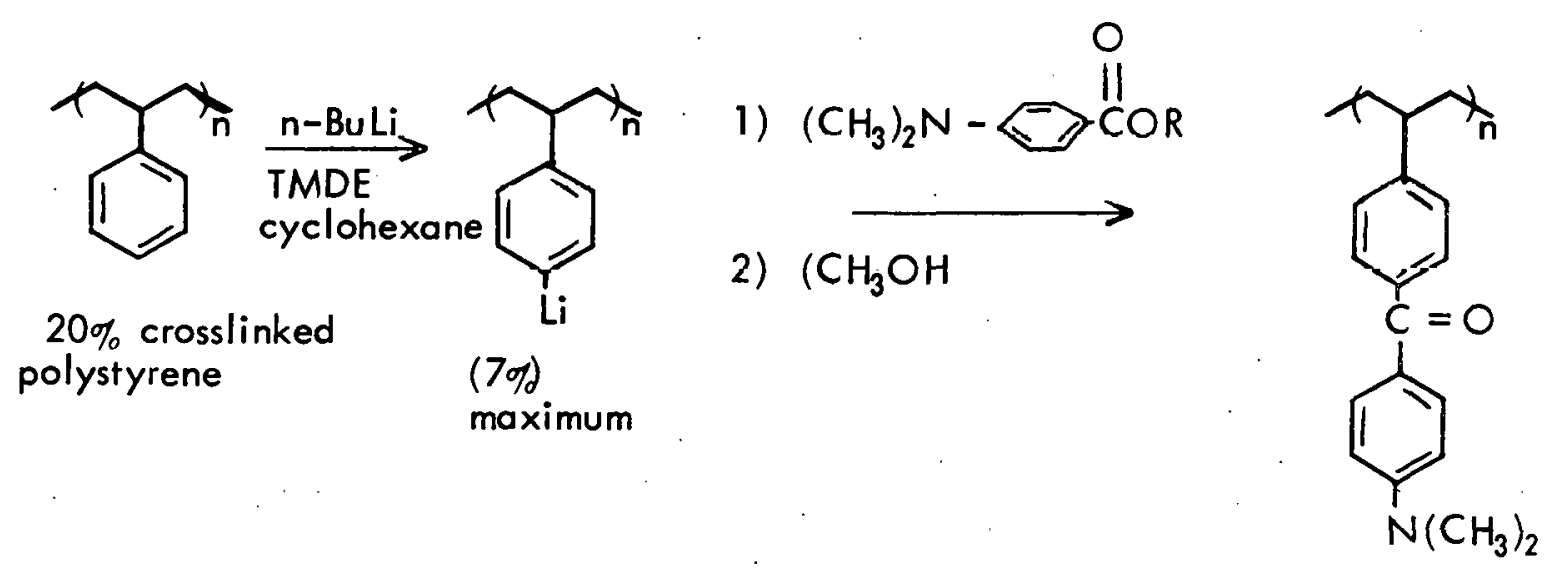

Polymer $N-A$ : using ester $R=E \dagger$ Polymer $N-\bar{B}$ : using ester $R=M e$ 
Table 3. Ratio of Quantum Efficiency at $406 \mathrm{~nm}$ to that at $366 \mathrm{~nm}$

$\begin{array}{ll}\text { Polymer } & \quad \frac{\text { Ratio }}{N-A} \\ N-B & 0.14 \\ & 0.28\end{array}$

that expectation. In either case, the maximum degree of functionalization is determined by the degree of lithiation which was kept at $7 \%$ in both cases.

A common practice in experimental photochemistry for measuring quantum efficiencies is to make such measurements at very low chemical conversions ( 1 to $5 \%$ ). Numerous reasons make low conversion measurements more reliable for mechanistic studies. Among these is the fact that the substrate (norbornadiene) concentration decreases through the course of a conversion. The extent to which this occurs was studied by measuring quantum efficiencies (at low conversions) for several initial concentrations of norbornadiene (Table 4) and by measuring the drop in quantum efficiency as a function of conversion (Table 5). By analyzing the data in Table 4 using a standard Stern-Vollmer treatment, ${ }^{2}$

Table 4. Quantum Efficiency as a Function of Initial Norbornadiene Concentration (System: Polymer $\mathrm{N}$ in hexane solvent irradiated at $366 \mathrm{~nm}$ to low conversions)

$\begin{array}{cc}\text { Norbornadiene conc. (initial) } & \phi \\ 0.51 & 0.45 \\ 0.30 & 0.26 \\ 0.10 & 0.18 \\ 0.05 & 0.12\end{array}$

intercept to slope ratios can be compared with the analogous sensitization in homogeneous solution. The values so obtained are 6.0 and 6.3 for the polymeric and solution studies respectively. A large value is indicative of an efficient system insensitive to substrate concentration. The data in Table 5 are consistent with a decrease in quantum efficiency resulting merely from a gradual change in norbornadiene concentration. 
Table 5. Quantum Efficiency as a Function of Percent Conversion (System: Polymer N in hexane irradiated at $366 \mathrm{~nm}$ with an initial norbornadiene concentration of $0.3 \mathrm{M}$ )

$\begin{array}{cc}\text { Percent Conversion } & \frac{\phi}{1.2} \\ 3.7 & 0.25 \\ 7.6 & 0.25 \\ 43 . & 0.26 \\ 81 . & 0.23 \\ & 0.17\end{array}$

This quarter, several studies involving the use of butylated hydroxy tolvene (BHT) were conducted to explore the potential use of this material as a stabilizing agent for our prototype recycling device. Stabilizing agents are frequently added commercially to olefins to prevent polymerization and oxidation. We have found that this particular inhibitor interferes with and is degraded under the photochemical sensitization conditions. For example, the addition of BHT, in the homogeneous sensitization studies, results in lowering the quantum efficiency for sensitization by about $30 \%$ (measured at $6 \%$ conversion) Interestingly, when an identical study was conducted using the polymeric $N$ sensitizer, no significant decrease in sensitization efficiency was observed. These results apply to a $0.11 \%$ solution of BHT in hexane. Further studies are necessary to determine: (I) if stabilizers are needed in the system and (2). if the polymeric system is totally immune to the deleterious effects of such stabilizers.

\section{POLYMERIC INORGANIC SENSITIZERS}

In the last quarterly report, 3 we presented our initial findings on the first noncopper containing inorganic sensitizer, $\operatorname{Ir}(\text { bipy })_{2}$ (bipy $\left.^{\prime}\right) \mathrm{OH}^{+2}$ (where bipy' denotes

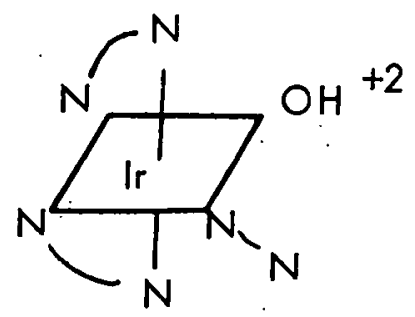


a monodentate bipyridine ligand). It was suggested that the presence of a polar solvent (needed to dissolve the +2 ion) may have led to undesirable side reactions of the sensitizer, thus accounting for the relatively low quantum yield $(\sim 0.1)$ for quadricyclene production. A similar interaction with solvent may be responsible for the lack of sensitization " ${ }^{1} 4$ by other transition metal compounds possessing relatively high energy triplet states, e.g. Ir (phen $)_{2} \mathrm{Cl}_{2}^{+}, \mathrm{Rh}$ (phen $)_{3}^{+3}$. An attractive strategy for eliminating the need for a polar solvent involves immobilizing the charged sensitizer onto an appropriate polymeric ion exchange resin. Thus we have recently immobilized $\operatorname{Ir}(\mathrm{phen})_{2} \mathrm{Cl}_{2}{ }^{+}$. onto sulfonated styrene-divinylbenzene copolymer beads. A sample of this material in contact with a $0.5 \mathrm{M}$ norbornadiene-benzene solution was irradiated with $366 \mathrm{~nm}$ light.

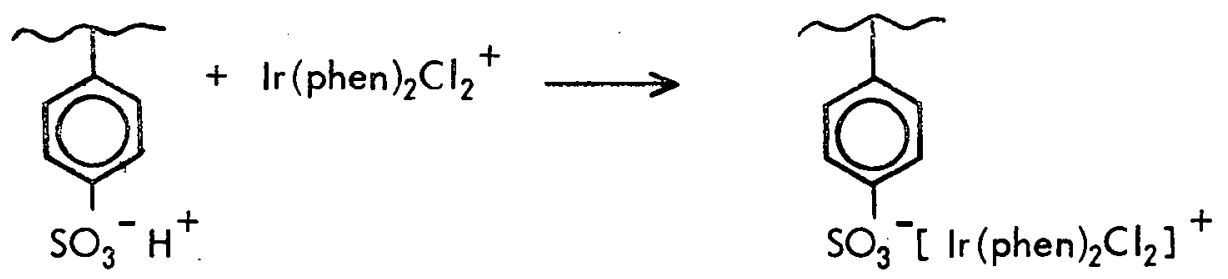

The quantum yield for quadricyclene production is at least 0.05 . By comparison, no sensitization is observed if a homogeneous solution of $\operatorname{Ir}(\mathrm{phen})_{2} \mathrm{Cl}_{2}{ }^{+}$and norbornadiene in $20 \%$ ethanol-80\% benzene solution is irradiated at the same wavelength.

This very promising initial result with a polymer immobilized inorganic sensitizer is currently being examined in more detail with the aim of optimizing the sensitization efficiency. A thorough study of sensitization by polymer bound $\operatorname{Ir}$ (bipy) (bipy $\left.^{\prime}\right) \mathrm{OH}^{+2}$ is also planned.

\section{CATALYSIS OF THE CONVERSION OF NORBORNADIENE TO QUADRICYCLENE}

During this quarter the portion of this project concerned with catalysis has concentrated on developing a more detailed understanding of the cobalt (II)porphyrin, palladium(II) phosphine, and triphenylcyclopropenylnickel catalyst systems discussed in previous quarterly reports. 3 We have begun some kinetic studies with the polystyrerieanchored catalysts in order to establish the catalytic activities relative to metal conten: of the different types of structures. In addition new structure-activity relationships have 
been observed in the triphenylcyclopropenylnickel complexes.

Details of our work on these specific systems are outlined below.

\section{A. Polymer-anchored Cobalt (II) Porphyrin Catalysts}

Since the last quarterly report ${ }^{3}$ some quantitative kinetic studies have been performed on the catalysis of the conversion of quadricyclene to norbornadiene using the polymer-anchored cobalt(II) porphyrin catalysts. In most of the work the carbox amido-linked cobalt(II) porphyrin supported on polystyrene schematically represented as I was used.<smiles>O=CO</smiles>

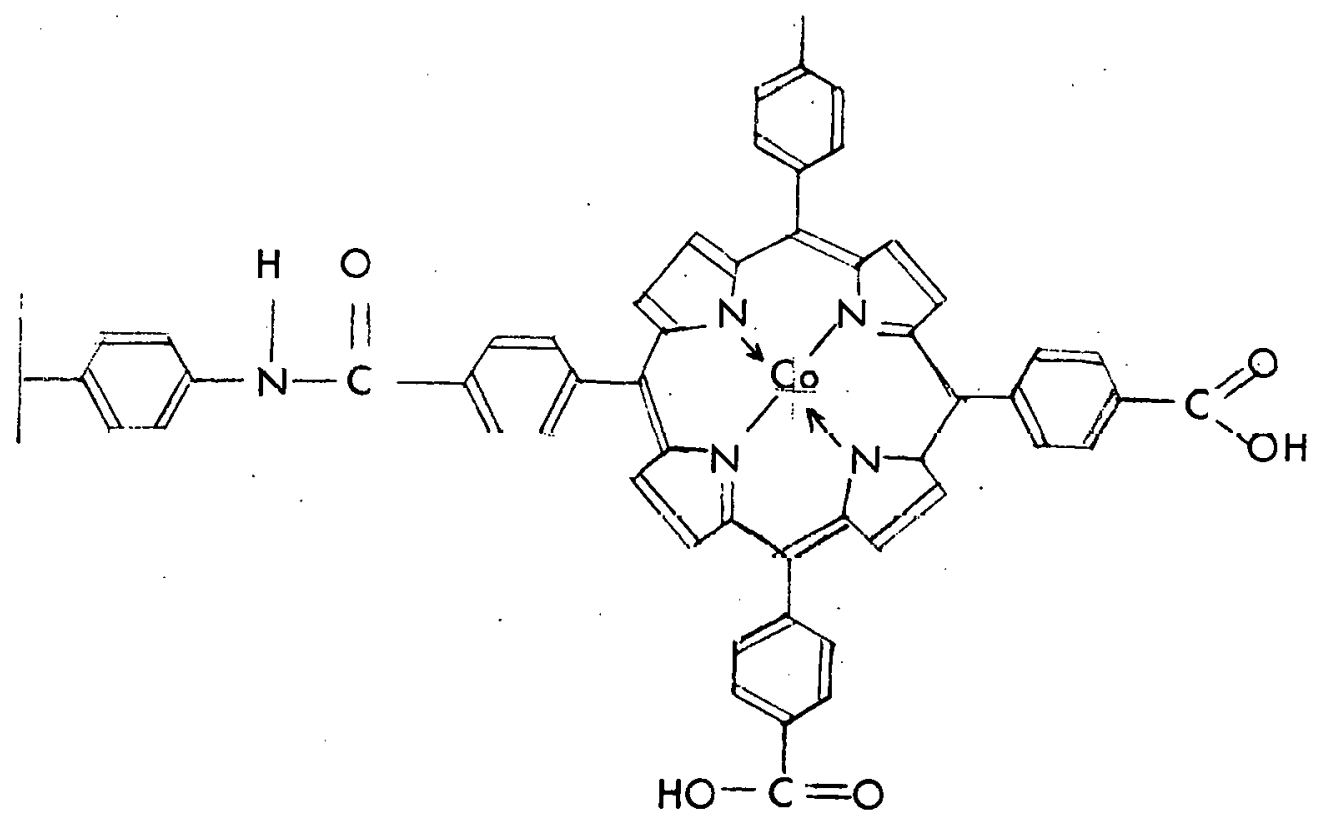

In this kinetic work about $0.1 \mathrm{~g}$. of the cobalt (II) porphyrin polymer I contcining $0.44 \%$ Co was allowed to react at $30 \pm 0.1^{\circ}$ with $10.0 \mathrm{ml}$. of $1.00 \mathrm{M}$ quadricyciane in xylene containing $0.25 \mathrm{M}$ benzene as an internal gas chromatography standard. Samples ( 40 microliters) of the reaction mixture were withdrawn at about 5 minute intervals (measured to $\pm 0.1 \mathrm{~min}$.) dilute to $1.0 \mathrm{ml}$. with pentane, and analyzed by gas chromatography using $0-1 / 8 " \times 1017.8 \%$ SF-96 on Chromsorb $W$ column with a $60 \mathrm{ml} . / \mathrm{min}$. nitrogen flow and a flame ionization detector. Concentrations were determined from the peak area ratius of quadricyclene to benzene compared to the ratio at zero time and $1.00 \mathrm{M}$ quadricyclane concentration. After each run the polymer was washed for at least 10 minutes each three times with fresh xylene and dried under vacuum at $60^{\circ}$. 
The observed first order rate constants $k_{0}$ were obtained from a linear least. squares plot of - In (concentration) versus the reaction time in minutes. The $k_{0}$ were then converted to a normalized rate constant through the formula $k=k_{0} V /(60 \mathrm{~W})$ where $V$ is the volume of solution in liters, $W$ is the weight of catalyst in grams, and the 60 converts the time scale from minutes to seconds. All plots were approximately linear over 5 to 7 half lives. A rate constant based on metal concentration, $k_{m}$, was also calculated.

The data from these experiments on the carboxamido-linked cobalt (II) porphyrin polymer 1 are summarized in Table 6 where the indicated sequence numbers refer to recycling the same sample of polymeric catalyst after the xylene washing and drying outlined above. In all cases the rate constant $k$ was found to decrease with repeated recycling of the same batch of the cobalt(II) porphyrin polymer. This decrease of activity upon recycling is less severe in the series of runs performed under nitrogen, but it is still significant. A plot of the rate constant $k$ versus the quantity of solution to which the catalyst has been exposed is fairly linear suggesting that some component of the solution is causing deactivation of the catalysts. Further work is planned in an attempt to determine this source of catalyst deactivation upon repeated use.

\section{B. Polymer-anchored Palladium (II) Phosphine Catalysts}

The last quarterly report ${ }^{3}$ mentioned a new palladium(II) complex of diphenylphosphinated polystyrene which was an active polymer-anchored catalyst for the conversion of quadricyclane to norbornadiene. This catalyst has been studied in more detail during this quarter.

Macroreticular polystyrene beads were diphenylphosphinated by treatment with n-butyllithium followed by treatment with diphenylchlorophosphine. ${ }^{5}$ Palladium(II) chloride was complexed with this polymer by stirring in acetonitrile solution. The resulting lemon yellow beads were an active catalyst for the conversion of quadricyclane to norbornadiene and gave the following analysis: $\mathrm{Pd}, 0.70 \% ; \mathrm{P}, 0.28 \% ; \mathrm{Cl}, 0.39 \%$ This analysis corresponds to a $\mathrm{Pd} / \mathrm{P} / \mathrm{Cl}$ ratio of $1.0 / 1.4 / \mathrm{I} .7$. These analytical data are insufficient to define an exact structure for this polymer. However, the structure schematically represented as II is not inconsistent with our data when considered in light of expected experimental errors in the analysis of such systems.

The kinetic studies on the catalysis of the conversion of quadricyclane to norbornadiene by this palladium polymer 11 were performed in air at $30^{\circ}$ using an experimental 


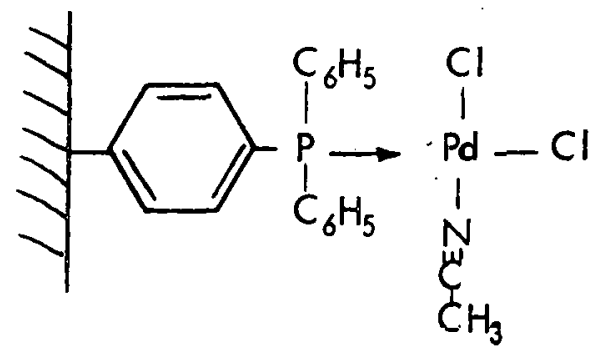

procedure very similar to that described above for the kinetic work on the polymericanchored cobalt (II) porphyrin catalysts. The resulting data are given in Table 7 .

The preliminary kinetic results (Table 7) indicate that the initial activity of the polymer-anchored palladium(II) catalysts II decreases slightly upon recycling but retains this lowered activity upon further recycling. This contrasts with the polymer-anchored cobalt (II) porphyrin complex I (Table 6) which appears to suffer continual losses of activity upon repeated recycling. The loss of activity of the polymeric palladium catalyst II on the first but not on subsequent recycling could arise either from metal leaching from the polymer or from formation of a palladium-norbornadiene complex on the polymer which would lower the accessibility of the coordination sites on the palladium. Further work is planned in order to define more precisely this loss of catalytic activity.

C. Triphenylcyclopropenyl Nickel Complexes as Catalysts

Several months ago 1,3 in connection with this program we discovered that the triphenylcyclopropenylnickel carbonyl halides ${ }^{6}\left[\left(\mathrm{C}_{6} \mathrm{H}_{5}\right)_{3} \mathrm{C}_{3} \mathrm{Ni}(\mathrm{CO}) \mathrm{X}\right]_{2} \quad(\mathrm{X}=\mathrm{Cl}$ and $\mathrm{Br})$ were active catalysts for the conversion of quadricyclane to norbornadiene. Subsequent work ${ }^{3}$ has been concerned with the preparation of additional triphenylcycloproperiy Inickel complexes for catalyst evaluation. In this way we hope to define the structural features of triphenylcyclopropenylnickel complexes necessary to give them the desired catalytic properties.

In this previous work we noted that reactions of $\left[\left(\mathrm{C}_{6} \mathrm{H}_{5}\right)_{3} \mathrm{C}_{3} \mathrm{Ni}(\mathrm{CO}) X\right]_{2}(\mathrm{X}=$ $\mathrm{Cl}$ and $\mathrm{Br})$ with alkylmagnesium halides $\mathrm{RMgX}\left(\mathrm{R}=\mathrm{CH}_{3}, \mathrm{C}_{2} \mathrm{H}_{5},\left(\mathrm{CH}_{3}\right)_{2} \mathrm{CH},\left(\mathrm{CH}_{3}\right)_{3} \mathrm{C}\right.$, and $\mathrm{C}_{6} \mathrm{H}_{5}$ ) and with potassium acetate, propionate, benzoate, and o-methylbenzoate all gave dark gray colored powders which had strong catalytic activity for the conversion of quadricyclane to norbornadiene. To date we have been unable to obtain pure samples 
of these apparently ill-defined substances for more detailed identification and characterization. The one definite feature of all of these materials is the absence of an infrared $\nu(\mathrm{CO})$ frequency indicating that the carbonyl groups in $\left[\left(\mathrm{C}_{6} \mathrm{H}_{5}\right)_{3} \mathrm{C}_{3} \mathrm{Ni}(\mathrm{CO}) X\right]_{2}$ were lost in all of their reactions with organomagnesium compounds and with carboxylates.

In view of the difficulty in identifying these rather intractable nickel complexes, we have explored another approach to the preparation of triphenylcyclopropenyl complexes based on the reactions of $\left[\left(\mathrm{C}_{6} \mathrm{H}_{5}\right)_{3} \mathrm{C}_{3} \mathrm{Ni}(\mathrm{CO}) \mathrm{Cl}_{2}\right.$ with Lewis base donor ligands according to the following probable sequence of reactions:

$$
\begin{aligned}
& {\left[\left(\mathrm{C}_{6} \mathrm{H}_{5}\right)_{3} \mathrm{C}_{3} \mathrm{Ni}(\mathrm{CO}) \mathrm{Cl}\right]_{2}+2 \mathrm{~L} \longrightarrow 2\left(\mathrm{C}_{6} \mathrm{H}_{5}\right)_{3} \mathrm{C}_{3} \mathrm{NiLCl}+2 \mathrm{CO}} \\
& \left(\mathrm{C}_{6} \mathrm{H}_{5}\right)_{3} \mathrm{C}_{3} \mathrm{NiLCl}+\mathrm{L} \longrightarrow\left(\mathrm{C}_{6} \mathrm{H}_{6}\right)_{3} \mathrm{C}_{3} \mathrm{Ni} \mathrm{L}_{2} \mathrm{Cl}
\end{aligned}
$$

The compounds of this type which have been prepared along with their catalytic activities are summarized in Table 8 . In these cases it appears possible to obtain yellow. to dark red crystalline complexes although only $\left(\mathrm{C}_{6} \mathrm{H}_{5}\right)_{3} \mathrm{C}_{3} \mathrm{Ni}\left(\mathrm{PCl}_{2} \mathrm{C}_{6} \mathrm{H}_{5}\right)_{2} \mathrm{Cl}$ has been obtained analytically pure.

There are two particularly interesting points about these triphenylcyclopropenylnickel compounds:

(1) Complexes of the stoichiometry $\left(\mathrm{C}_{6} \mathrm{H}_{5}\right)_{3} \mathrm{C}_{3} \mathrm{NiLCl}$ are generally more active catalysts than complexes of the stoichiometry $\left(\mathrm{C}_{6} \mathrm{H}_{5}\right)_{3} \mathrm{C}_{3} \mathrm{Ni} \mathrm{L}_{2} \mathrm{Cl}$ presumably because the extra equivalent of ligand in the latter complexes blocks needed coordination sites.

(2) Organophosphorus ligands giving triphenylcyclopropenylnickel halide complexes of appropriate activity provide a possible "handle." to anchor triphenylcyclopropenylnickel systems onto polymers. Thus the activity of $\left(\mathrm{C}_{6} \mathrm{H}_{5}\right)_{3} \mathrm{C}_{3} \mathrm{NiP}\left(\mathrm{C}_{6} \mathrm{H}_{5}\right)_{3} \mathrm{Cl}$ suggests that the polymeric catalyst obtained from $\left[\left(\mathrm{C}_{6} \mathrm{H}_{5}\right)_{3} \mathrm{C}_{3} \mathrm{Ni}(\mathrm{CO}) \mathrm{Cl}_{2}\right]_{2}$ and the diphenylphosphinated polystyrene ${ }^{5}$ used for the palladium (II)complex II discussed above might be an active catalyst.

Further experiments are planned in order to characterize more fully these new triphenylcyclopropenylnickel complexes by the usual analytical and spectroscopic techniques, to provide a more detailed understanding of the relationships between their structures and catalytic activities, and to anchor active triphenylcyclopropenylnickel catalyst systems onto polymers by using appropriate polymeric organophosphorus ligands such as the diphenylphosphinated polystyrene discussed above. 
TABLE 6

KINETIC DATA FOR THE CONVERSION OF QUADRICYCLANE TO NORBO RNADIENE BY THE PCLYSTYENE-ANCHORED AMIDO-LINKED COBALT(II) TETRAPHENYLPORPHYRIN(I)

Sequence $\quad k\left(\sec ^{-1}(\text { g. } / 1 .)^{-1}\right) \quad k_{M}\left(\sec ^{-1}(g .-\operatorname{atom~Co} / 1 .)^{-1}\right.$

A. Runs in air

Fresh Catalyst

Recycle

$1.3 \times 10^{-4}$

1.7

$0.91 \times 10^{-4}$

1.2

B. Runs under nitrogen

Fresh Catalyst

First Recycle

Second Recycle

Third Recycle

Fourth Recycle

$$
\begin{aligned}
& 1.7 \times 10^{-4} \\
& 1.5 \times 10^{-4} \\
& 1.3 \times 10^{-4} \\
& 1.2 \times 10^{-4} \\
& 0.99 \times 10^{-4}
\end{aligned}
$$

1.9

1.8

1.6

1.2 
TABLE 7

KINETIC DATA FOR THE CONVERSION OF QUADRICYCLANE TO NORBORNADIENE BY THE POLYSTYRENE-ANCHORED PALLADIUM(II) TRIARYLPHOSPHINE CHLORIDE COMPLEX

Sequence

Fresh Catalyst

First Recycle

Second Recycle $k^{c}\left(\sec ^{-1}(g . /)^{-1}\right)$ $2.8 \times 10^{-5}$

$1.6 \times 10^{-5}$

$1.7 \times 10^{-5}$
$k_{M}\left(\right.$ sec. $\left.^{-1}(\text { g. -átom Pd/l. })^{-1}\right)$

$$
0.42
$$

0.24

0.26 
TABLE 8

STUDIES ON $\left(\mathrm{C}_{6} \mathrm{H}_{5}\right)_{3} \mathrm{C}_{3} \mathrm{NiL}{ }_{n} \mathrm{Cl}$ SYSTEMS AND THEIR CATALYTIC ACTIVITIES FOR THE CONVERSION OF QUADRICYCLANE TO NORBORNADIENE

\begin{tabular}{|c|c|c|}
\hline Compound $^{a}$ & Color & Catalytic Activity $^{b}$ \\
\hline $\mathrm{Ph}_{3} \mathrm{C}_{3} \mathrm{Ni}\left(2,2^{\prime}\right.$ 'bipy $) \mathrm{Cl}^{\mathrm{C}}$ & dark red & + \\
\hline $\mathrm{Ph}_{3} \mathrm{C}_{3} \mathrm{Ni}\left(\mathrm{PPh}_{2} \mathrm{Me}\right) \mathrm{Cl}$ & brown & + \\
\hline $\mathrm{Pl}_{3} \mathrm{C}_{3} \mathrm{Ni}\left(\mathrm{PPh}_{2} \mathrm{Me}\right) \mathrm{Cl}$ & dark orange & + \\
\hline $\mathrm{Ph}_{3} \mathrm{C}_{3} \mathrm{IN}\left(\mathrm{PPH}_{3}\right) \mathrm{Cl}^{\mathrm{C}}$ & dark brown & ++ \\
\hline $\mathrm{Ph}_{3} \mathrm{C}_{3} \mathrm{Ni}\left(\mathrm{PPh}_{3}\right)_{2} \mathrm{Cl}$ & dark red & + \\
\hline $\mathrm{Ph}_{3} \mathrm{C}_{3} \mathrm{Ni}\left[\mathrm{P}(\mathrm{OPh})_{3}\right] \mathrm{Cl}^{\mathrm{c}}$ & brown & $++t$ \\
\hline $\mathrm{Ph}_{3} \mathrm{C}_{3} \mathrm{Ni}\left[\mathrm{P}(\mathrm{OPh})_{3}\right]_{2} \mathrm{Cl}$ & orange & - \\
\hline $\mathrm{Ph}_{3} \mathrm{C}_{3} \mathrm{Ni}\left[\mathrm{P}(\mathrm{OMe})_{3}\right]_{2} \mathrm{Cl}$ & orange & - \\
\hline $\mathrm{Ph}_{3} \mathrm{C}_{3} \mathrm{Ni}\left[\mathrm{P}\left(\mathrm{OPr}^{\mathrm{i}}\right)_{3}\right]_{2} \mathrm{Cl}$ & orange & - \\
\hline $\mathrm{Ph}_{3} \mathrm{C}_{3} \mathrm{Ni}\left(\mathrm{PPh}_{2} \mathrm{Cl}\right)_{2} \mathrm{Cl}$ & yellow & - \\
\hline $\mathrm{C}_{3} \mathrm{Ni}\left(\mathrm{PPhCl}_{2}\right)_{2} \mathrm{Cl}^{\mathrm{C}}$ & yellow & +++ \\
\hline
\end{tabular}

a) 2,2'-bipy $=2,2^{\prime}$-bipyridyl; $\mathrm{Me}=$ methyl; $\mathrm{Pr}^{i}=$ isopropyl; $\mathrm{Ph}=$ phenyl

b) The catalytic activities are indicated as follows:

- no detectable activity

+ minimum detectable activity ( 5 to $10 \%$ conversion even upon prolonged standing at room temperature

++ moderate activity (some conversion in short periods at room temperature; major amounts of conversion at higher temperatures or prolonged standing at room temperature.

+++ high activity resulting in on immedinte exnthermis nearly complete conversion of quadricyclane to norbornadiene

c) These approximate compositions were verified by carbon and hydrogen analyses. 


\section{REFERENCES}

1. Quarterly report for ERDA Contract E(38-1)-893, September 15, 1976.

2. R. R. Hautala, J. Little and E. M. Sweet, Solar Energy, 19, in press (1977).

3. Quarterly report for ERDA Contract E(38-1)-893, December 15, 1976.

4. C. Kutal, D. P. Schwendiman, and P. Grutsch, Solar Energy, 19, in press (1977).

5. D. C. Evans, M. H. George, and J. A. Barrie, J. Polym. Sc., Polym. Chem. Ed., 12,247 (1974).

6. E. W. Gowling and S. F. A. Kettle, Inorg. Chem., 4, 604 (1965). 